\title{
Bangladesh-Myanmar Border Relations: A Study of Some Geopolitical and Economic Issues
}

\author{
Akkas Ahamed, \\ Mohammad Alam Chowdhury, \\ Associate Professor, Department of Political Science, \\ University of Chittagong, Bangladesh \\ Md. Sayedur Rahman,
} Assistant Professor, Department of Political Science, Faculty of Social Sciences, Begum Rokeya University, Rangpur, Bangladesh \& Masters Student, Masters Programme in Socioeconomic and Political Development of Modern Asia, Faculty of World Economy and International Affairs, National Research University Higher School of Economics, Moscow, Russian Federation

Doi:10.19044/esj.2020.v16n22p320 URL:http://dx.doi.org/10.19044/esj.2020.v16n22p320

\begin{abstract}
Myanmar is a neighboring country of Bangladesh with long border. It has huge natural resources such as oil, gas, forestry, fisheries, agricultural land and other mineral resources. Myanmar is a country with an easy access to South Asia, South East Asia, and North East Asia. It is also linked with the Bay of Bengal and Indian Ocean which have strategic importance for navigation, trade, and investment purposes. Two-neighboring countries, China and India, are both beneficiaries through maintaining friendly relations with Myanmar. Both China and India are using Myanmar's ports, Bay of Bengal and Indian Ocean, for exports and imports. They have also invested a huge amount of money in the different development projects including oil, gas, electricity, regional connectivity, and special economic zones in Rakhine state. The result of the study shows that the relationship between Bangladesh and Myanmar is not very good diplomatically. Bangladesh, being a close neighbor, has not been able to be benefit from Myanmar's natural resources, strategic location, and trade and investments. It is high time for Bangladesh to look at the potentials that are important in terms of its geo-strategic, geopolitical, and economic interests. The crisis of Rohingya ethnic minority occurs as a result of the lack of intimate relationship between Bangladesh and Myanmar. This paper focuses on pointing out the bilateral problems between these two countries. It also aims to provide some policy recommendations for both countries, particularly Bangladesh, which is suffering tremendously due to
\end{abstract}


Rohingya influx. This study recommends that Bangladesh government should take necessary steps to maintain the relationship with Myanmar's government to resolve the bilateral border issues amicably. To carry out this study, both secondary and primary data were used qualitatively.

Keywords: Bangladesh, Myanmar, Border Relations, China, Rohingya, Bay of Bengal, Gas

\section{Introduction}

The successive regimes in Myanmar had been very particular and effective in protecting its national interests. They had been playing their cards very carefully and shrewdly. Study of Myanmar's foreign policy is very interesting and thought-provoking. Foreign policy is formulated within an environment which is influenced by many factors. In this paper, significant aspect of Myanmar's foreign policy have been discussed (Ahmad, 2017).

Myanmar, previously known as Burma, has been described as "an insane, beautiful, challenging, and hilarious country" by Will Hatton, a backpack traveler. It has abundance of natural resources such as petroleum, tin, timber, copper, zinc, tungsten, coal, lead, some marble, limestone, natural gas, precious stones, and hydropower. Myanmar has the largest jade and ruby mines in the world with very good quality. Myanmar also has sapphires and diamonds. It also has one of the best quality timbers in the world. It is home to one of the world's oldest petroleum industries, with its crude oil exports dates back to 1853 (Ahmad, 2017; Maung, 2016).

Myanmar occupies a strategic location bordering the two ascending powers, i.e., China and India, and it is connected with the Indian Ocean through the Bay of Bengal. It is the only land transportation hub connecting East Asia, Southeast Asia, and South Asia. Its location of geo-strategic importance has made it the focus of interests for the world's major powers such as China, Japan, the United States, India, and the European Union (Ahmad, 2017; Dai \& Hongchao, 2014). In Samuel Huntington's terms, it is located in the lines of three major civilizations, those of the Hindus, Buddhists, and Confucians (Selth, 2001; Ahmad, 2017).

However, the election of 2010 gave a new type of governance to Myanmar and a new appearance to the state. Although the government was composed of mostly retired military officers, they presented a complete different façade. The newly elected President, retired General Thein Sein, in his inaugural speech highlighted that they will continue with the foreign policies adopted by the previous military regimes. He emphasized that Myanmar will stand firm as a respected member of the global community, and the country is ready to take on the challenges of the twenty-first century in a bold and resolute manner (Sein, 2016; Ahmad, 2017). In 2015, he further reiterated that Myanmar intends to become a respectable, dutiful, and 
responsible nation; and it also wants to come out of international sanctions and isolation (Sein, 2016).

Therefore, this was a departure from the previous regimes' policies, where people to people contact was kept in a minimum level. The Ministry of Information's write-up further elaborates: "It is essential to pursue people-topeople contacts to improve the understanding of the actual situation in Myanmar and the country's external and internal policies. After many decades of separation of Myanmar from the world, and of the world from Myanmar, the country desires more visits, exchanges of views and interactions with political leaders, academic scholars, students, civil society groups and tourists from other nations" (Ahmad, 2017). Careful attention should be given to real arrangements, including an effective immigration policy for external visitors.

The new democratic government has been pursuing its foreign policy objectives with more firmness and deft. Daw Suu Kyi visited Beijing and ASEAN capitals, and in September she visited the USA. These visits indicated her priorities as well her eagerness to develop a personal rapport with the world leaders (Chow, 2016). She convinced the Obama administration to lift economic and political sanctions. Accordingly, the USA lifted most of the sanctions in October 2016 (Ahmad, 2017). Her diplomacy also worked when China, which was strongly supported by Russia, blocked a U.N. Security Council statement on Myanmar. The situation in Rakhine state is very worrying as the country's armed forces are carrying out a brutal attack on the Rohingya ethnic minorities (Reuters, 2017; Ahmad, 2017).

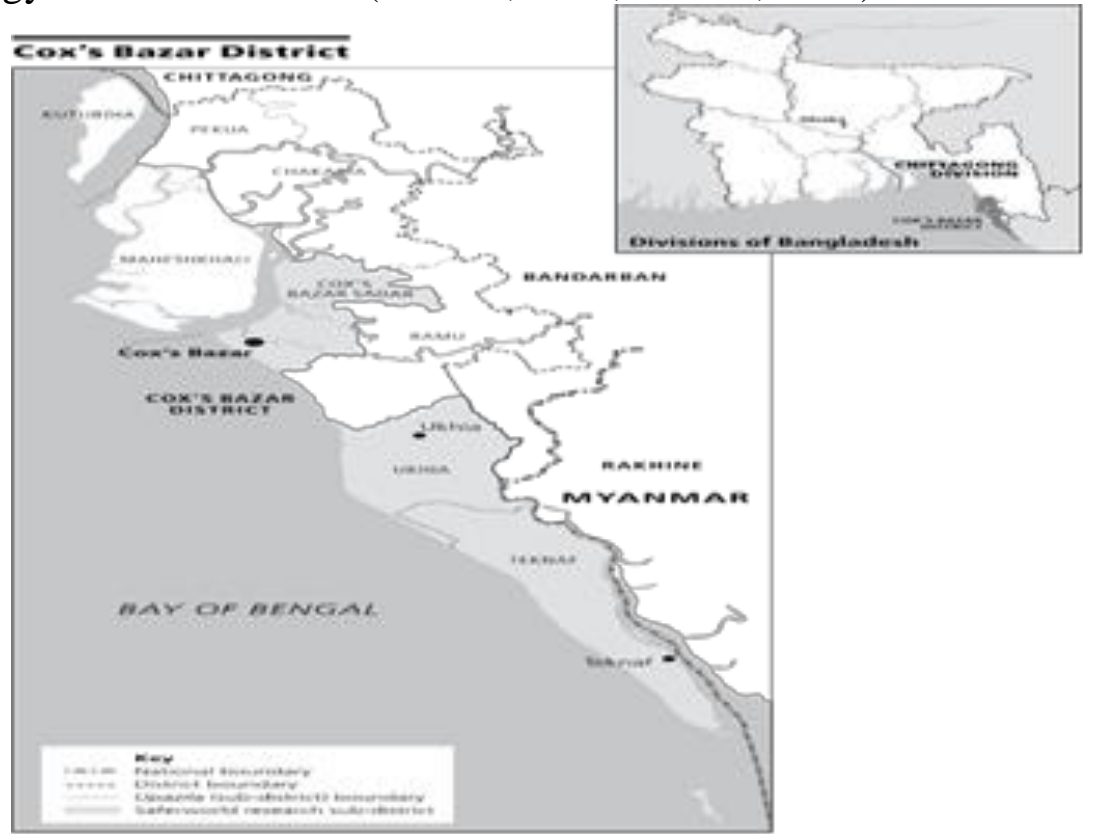

Figure 1. Bangladesh Myanmar Border, Source: Wikipedia (Also cited in Rashid, Ahamed \& Rahman, 2020) 
When the military of Myanmar launched its massive violence campaign in late August 2017, Bangladesh was initially reluctant to open its border to Rohingyas. Under international pressure, and on humanitarian grounds, the Rohingyas were allowed to enter into Bangladesh. Ever since then, Bangladesh has not been able to consolidate the international diplomatic cooperation required to conclusively put an end to the crisis (Alam, 2018).

\section{Study Objective}

Myanmar is a neighboring country of Bangladesh with long borders. It can provide certain strategic advantages to Bangladesh. It is a potential entrypoint for an alternative land road opening to China and South-East Asian countries other than the sea. Such road link has the potentiality for a greater communication network between Bangladesh and South-East Asian countries including Thailand, Malaysia, Laos, Cambodia, Vietnam, Indonesia, Singapore, and Brunei. Besides, with a huge natural resource-abundant country, Myanmar is a country with substantial potentials. Myanmar's forestry and other natural resources, for example: gas and stones, are huge from which Bangladesh can profit to a large extent. It is supposed that hostile relations with Myanmar can provide advantage to small rebel groups, which are active in the Chittagong Hill Tracts (Patwary, 2019). The study aims at pointing out the important border issues between Bangladesh and Myanmar that are creating barriers to the friendly relationship of the two countries. If China and India come forward to knock tie with Myanmar regarding the trade and investments, and economic development projects in Myanmar, Bangladesh would have an equal opportunity to take advantage of by promoting friendly relationship with Myanmar. Through this, many political issues can be resolved including the Rohingya problem. Moreover, Bangladesh can benefit from it both economically and politically, if it maintains warm relationship with Myanmar, which has huge arable land, gas, oil, fishes, and so many marine natural resources in the state of Rakhine bordering with Southeast Bangladesh, Cox’s Bazar.

\section{Study Method}

Both the districts of Bandarban and Cox's Bazar have borders with Myanmar's Chin and Rakhine state. However, this study has only surveyed two sub-districts of Cox's Bazar, Ukhia and Teknaf, purposively to study the border issues between Bangladesh and Myanmar. Bandarban district's border with Myanmar is very hilly and naturally difficult with many trees to collect primary data, and to observe the border situations clearly between the two countries. Thus, the study has only concentrated on Ukhia and Teknaf. This study has collected data using an unstructured method. Unstructured observation was conducted in an open and free manner. Advantages of 
observation-based data collection method are good in a sense that it has direct access to research area. It also has high levels of flexibility in the context of recordings of occurrences. The study has also conducted focus group discussions (FGD) with some key informants on Bangladesh-Myanmar border issues. In addition, secondary data on the several issues of BangladeshMyanmar border relations such as journal articles, daily newspapers, research monographs, relevant magazines, video documentaries and relevant books have been used in carrying out this study.

\section{Bangladesh-Myanmar Relations in the Context of Historical Perspective}

Myanmar is regarded as a buffer between the two Asian super powers, i.e., China and India. Its geographical location and natural resources have given it a significance position in South, South East Asian, and North East Asian regions. Myanmar got independence from Britain in 1948. There are different ethnic groups in Myanmar, of whom Barman, Karens, Shans, Kachins and Rohingyas are more important than others. The ancient name for Myanmar was Burma. The military government in 1989 changed the name of the country from Burma to Myanmar in the hope of rooting out different ethnic affiliations of the people of Myanmar. In spite of that, there are many religious groups which results to ethnic politics in Myanmar (Uddin \& Ahamed, 2011).

Like Myanmar, Bangladesh was also under the British colonial rule till 1947. Bangladesh obtained its independence from Pakistan in 1971 through a war of huge bloodshed. Bangladesh has some similarities with Myanmar in some regards. For instance, both the countries are anti-colonial and both have experienced varied degrees of ethnic clashes (Uddin \& Ahamed, 2011).

Both countries are developing and are striving for development, prosperity, security, and friendship. Myanmar is five times larger than Bangladesh according to its size, but the population of Myanmar is only 50 million, roughly one-third of that of Bangladesh. Around $88 \%$ of the people of Bangladesh are Muslims. On the other hand, $85 \%$ of the people of Myanmar are Buddhists, although Myanmar has a sizable proportion of Muslim population. Most of these Muslims are inhabitants of the Arakan province (now Rakhine), who are known as Rohingyas. Myanmar has 123 miles long border with Bangladesh, and its border crossing by the people of the two countries is very common (Uddin \& Ahamed, 2011). At present, illegal entrance by Bangladesh's citizens into Myanmar's territory has decreased dramatically due to border tensions and security concerns.

The official relationship between the two countries commenced while Bangladesh was part of Pakistan (1947-1971). The formal relationship between the independent Bangladesh and Myanmar was established on January 13, 1972. Myanmar was the sixth country to recognize Bangladesh. Myanmar rationalized its stand in the following words: "The government of 
Burma does not accept as principle, the solution of a country's internal problems by direct help and intervention of a foreign country's military organization. However, due to the existence of questions requiring immediate communications and actions, the government of Burma has recognized the state of Bangladesh and its government" (Ahmed, 2008; Uddin \& Ahamed, 2011). Since then, Myanmar had a good relationship with Bangladesh. Nevertheless, there have been several deadly clashes along the border areas between the two countries. The relationship between the two neighboring nations has been stable and peaceful till 2017. Subsequently, the country started to operate military attack on the Rohingyas to evacuate them due to religious, political, economic and cultural reasons, exploration of oil and gas in the Rakhine state, special economic zones, FDI, constructions of roads and high ways, constructions of ports by China and India in the Rakhine state, and Rakhine state's easy connectivity with the Bay of Bengal and Indian Ocean.

Therefore, crackdown was carried out based on land grabbing and development of the state of Rakhine to allow foreign investments.

The United States has termed the persecution of the Rohingya as 'ethnic cleansing', and it threatened to impose sanction on those responsible. Chinese Foreign Minister Wang Yi, in June 2018 at a bilateral meeting in Beijing, has given the assurance to his Bangladesh counterpart, AH Mahmood Ali, regarding the Rohingya issue. Explaining the condition of 1.1 million Rohingya people in Bangladesh, Minister Ali wanted China's active cooperation in the repatriation procedure. Former Malaysia Prime Minister, Mahathir Mohammad, had condemned the Myanmar government in 2018 at a UN meeting for the genocide of Rohingyas in Rakhine. He stated that: "He does not believe in the interference in the internal affairs of other nations. Nations are sovereign. But does it mean that they have a lawful right to kill their own publics, since they are independent nation?"(Rashid, 2019). However, Bangladesh and Myanmar, being close neighbor to each other, should come forward to resolve the issue amicably to ensure peace, security, stability, connectivity, and developments in the whole region.

\section{The Impacts of Rohingya Refugee Issues and Bangladesh Myanmar Border Relations}

Rohingya people are the ethnic minorities who have been living in the state of Rakhine in Myanmar bordering with Cox's Bazar for several hundred years. However, the military-backed government of Myanmar does not recognize them as their citizen. Thus, they were compelled to cross into the border of Bangladesh and to settle in Ukhia and Teknaf. However, it is important to mention here that as at present, the Rohingyas are creating so many socio-economic problems. They are also liable for deteriorating the law and order situations, environmental and health problems, and the spread of the 
different kinds of diseases in Ukhia and Teknaf to a large extent and in the entire country to some extent. The issue is also posing political and security threats to Bangladesh and the different regions of South Asia and South East Asia. The issue needs to be resolved as soon as possible to ensure peace, prosperity, security, and stability in the region.

In discussing the border relations between Bangladesh and Myanmar, it is important to talk about the Rohingya issue which is a big threat to Bangladesh. The district of Cox's Bazar has undergone a tremendous change in terms of development, environment, and tourism after a huge number of Rohingya influxes to the area. The impacts of Rohingya influx in Bangladesh are multifaceted, and it has long-term devastating effect on the local people, economy, and environment. It is important to describe that the coastal town and beaches of Cox's Bazar used to be Bangladesh's main tourist destination, but now the area is awash with foreign aid workers. The area's residential hotel and restaurant proprietors are flourishing economically, and many Bangladeshi citizens have gotten jobs at the charitable organizations.

Consequently, due to Rohingya influx in Cox's Bazar, the price of every commodity has increased dramatically and the local poor people have lost their jobs to the cheap labor of Rohingyas, which has a tremendous effect on local host community (Alam, 2018). The Rohingya people have also altered the demographics of Ukhia and Teknaf area, where Rohingya refugees now outnumber locals 2 to 1 . Out of the roughly 900,000 Rohingyas' camps, Kutupalong camp is the largest and most densely populated refugee settlement in the world (Alam, 2018).

NGOs are educating the Rohingyas in English and Burmese, but not in Bengali. The concerned authority does not want to assimilate the Rohingya people with the local community. Bangladesh government and its citizens are not interested in integrating the Rohingyas into the local community. Particularly, the local host communities are very worried about the Rohingya settlement in Ukhia and Teknaf. New born refugee children are barred from Bangladeshi nationality through either birth or marital relationship. The birthrate amongst the Rohingya people is also greatly higher than that of Bangladesh. Afterward, diphtheria broke out in December 2018 and the concerned authority launched a huge vaccination campaign. Public health officials are worried that waterborne and other infectious diseases might break out beyond the camp areas. They are also at risk of trafficking for sex, drugs, and cheap labor. Abul Kashem, head of a local NGO, Help Cox's Bazar, who is working to stop trafficking and raise consciousness among youth, notifies that organized crime networks are keen to abuse those displaced people as a result of the crisis (Alam, 2018).

The map below shows that the Rakhine state has long border with South East Bangladesh, Ukhia and Teknaf. It also shows that it has an easy 
access to the Bay of Bengal and Indian Ocean, through which it has turned it into a navigation hub for many countries of East Asia, South East Asia and South Asia particularly China and India. Geopolitically, the state of Rakhine is so important for Myanmar and other countries including USA, Japan, South Korea, and the European Union. There have been published huge reports that Rohigyas' evacuation from the state of Rakhine was for attracting foreign investments and infrastructural development, for oil and gas exploration, and for constructing gas pipelines between Myanmar and China and between Myanmar and India. Land was grabbed by the military through persecution from the Rohingyas to attract foreign investments in the state of Rakhine. Already, the state of Rakhine is being used by China and India in many ways such as ports, electric power plants, marine drive, tourism, and special economic zones.

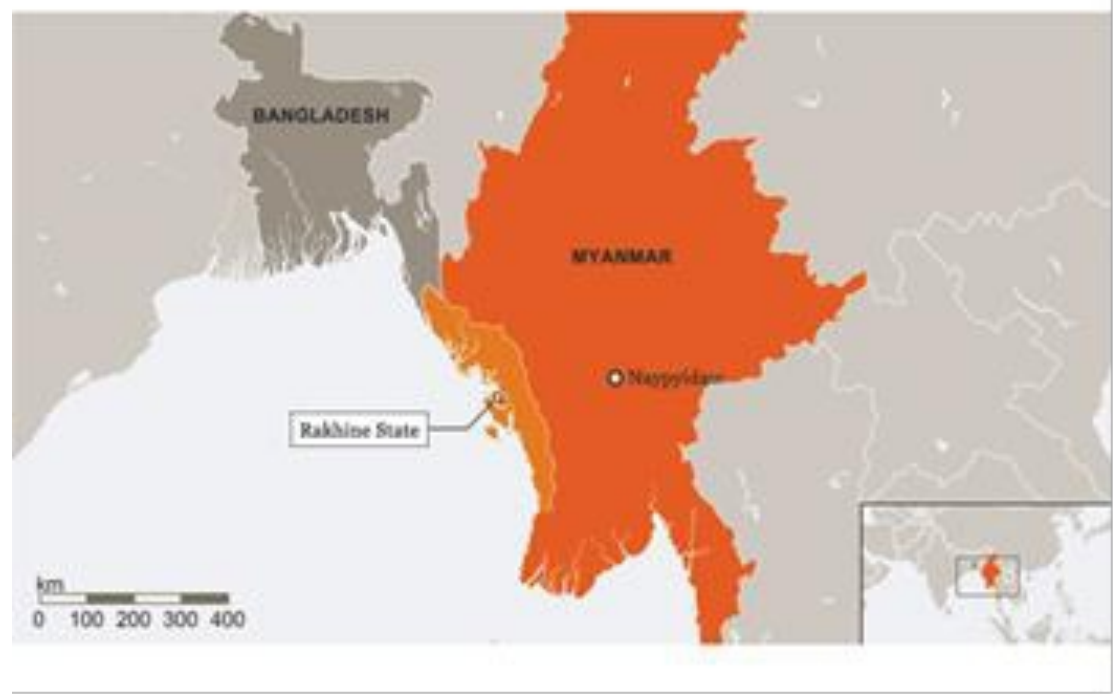

Figure 2.The Map of Bangladesh and Myanmar showing the state of Rakhine Source: Dhaka Courier, 2019

\section{Environmental Destruction in Ukhia and Teknaf Due to Rohingya Influx}

Bangladesh is highly vulnerable to environmental degradation or climate change. For years, the country has been facing soil erosion, rise of sea levels, and frequent natural disasters such as typhoons and floods. Landslides are tremendously probable. Groundwater sources are quickly being exhausted, and freshwater streams have become contaminated. Air pollution and related diseases in Ukhia and Teknaf have increased due to smoking from woods burned by refugees and the use of thousands of Lorries, jeeps, and cars carrying people and different kind of goods into the camps (Alam, 2018).

Moreover, the forest lands are being depleted and hills are being cut down for building of accommodations and camps for Rohingyas and different 
offices for NGOs. Thus, environmental threats are a major concern for the local people.

\section{Maritime Boundary Demarcation between Bangladesh and Myanmar}

Subsequently, there has been a long dispute between Bangladesh and Myanmar regarding the maritime boundary demarcation. On $14^{\text {th }}$ march 2012 , the Hamburg-based Law of the Sea Tribunal (ITLOS) delivered a historical judgment on delimitation of maritime boundary between Bangladesh and Myanmar. This judgment, which is first of its kind before the tribunal, has marked a distinctive legal success for Bangladesh. The dispute is about the demarcation of the territorial waters, continental shelves, and exclusive economic zones of both Bangladesh and Myanmar in the Bay of Bengal. The judgment also marks an important precedence that will be pertinent for resolving future maritime boundary disputes. Bangladesh has clearly won the case on the most substantial issues of the dispute (Faruque, 2013).

Currently, it is to make both parties in a dispute to easy understand why to defer to third-party resolution once the result are expected to accurately benefit both of them. The tribunal's decree was well-accepted with some degree of cordiality by both sides. Even more notably, the result was fixed; the two countries have not gone to conflict and have instead been competing to compromise the most satisfactory terms to international energy firms interested in natural gas reserves in the Bay of Bengal (Watson, 2015).

The case had its roots similarly in politics and law. Bangladesh has long concave coastline which makes maritime border disputes almost predictable. Under a regular application of maritime border law, the interconnecting arcs of 200 nautical miles of India's and Myanmar's exclusive economic zones (EEZs) would cut off Bangladesh's easy access to the continental shelf. Also, it would leave it with an excessively small EEZ in relation to the size of its coastline. Consequently, Myanmar and Bangladesh made contending claims to a segment of ocean and seabed covering southwest in a wide sliver from the seaward depot of their land. Consequently, the court's treatment of St. Martin's Island was important, which is a small island which is belonged to Bangladesh. Thus, it is located to the straight west of Myanmar.

The Tribunal gave complete effect to the island while demarcating the two countries' international seas, but did not permit Bangladesh to use the island as a center-point when marking the equidistance line between the two countries' EEZs and continental shelves. The judgment also reduced the island's importance by declining to recognize it as a "relevant circumstance" that would be considered when making adjustments to the maritime boundary line (Watson, 2015). 


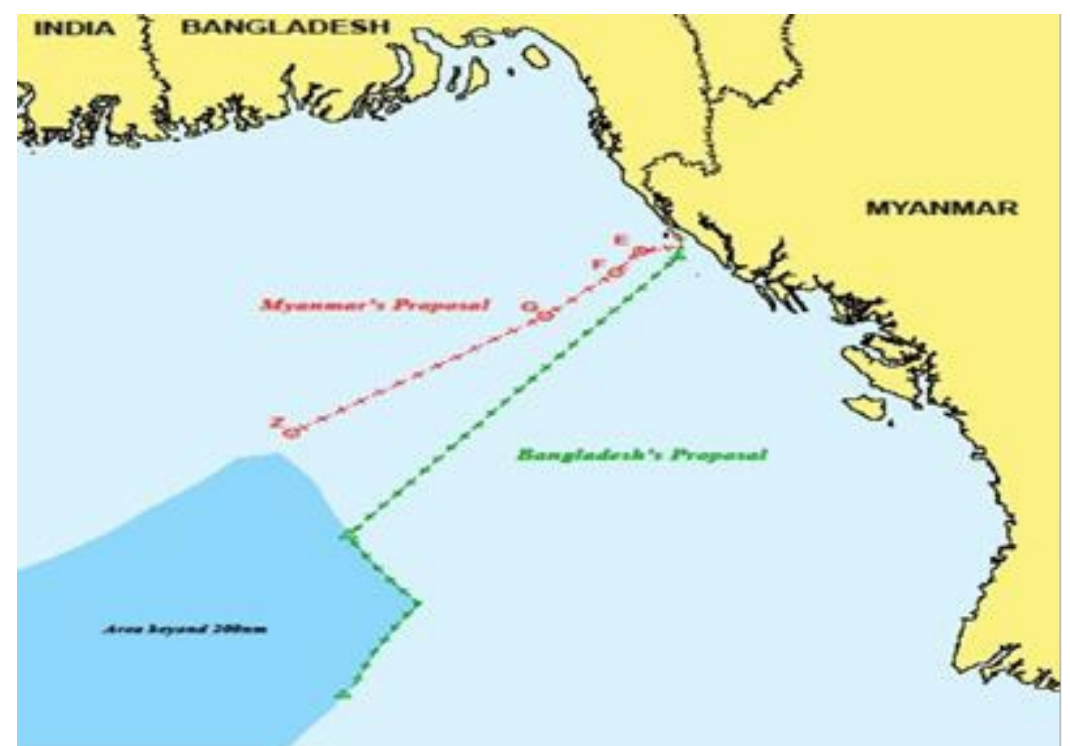

Figure 3. Sketch map composed by ITLOS illustrating the competing claims of Bangladesh (green) and Myanmar (red). Source: Watson (2015)

However, the treatment of St. Martin's island came in for robust criticism in the single opinion of Justice Zhiguo Gao, China's appointee on the tribunal, who explained the judgment to give full effect to the island in demarcating the international seas. This is aimed at overlooking it in demarcating the EEZ and continental shelf boundaries as "wrong and unacceptable." Gao further commented that the outcome of the judgment was unfair to Bangladesh, and that the island must be given half effect in demarcating the greater maritime boundary. In his separate view, he gave distinct weight to the island's degree of economic progress, the size of its inhabitants, and its closeness to the mainland, where he implied that in his opinion, not all islands are created equivalent for maritime boundary demarcation purposes. This argument over St. Martin has serious implications for small islands in undecided and disputed waters elsewhere in Asia (Watson, 2015). 


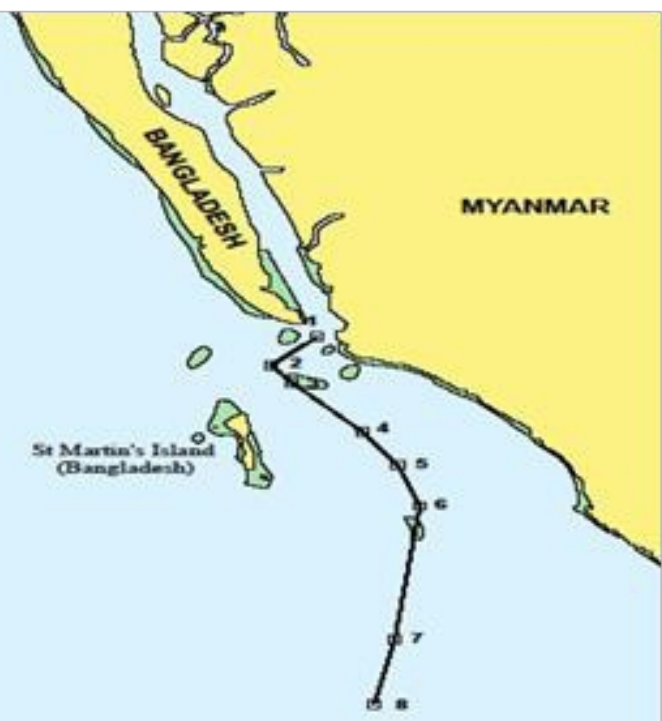

Figure 4. Sketch map composed by ITLOS showing St. Martin's Island's effect on the drawing of a territorial sea boundary between Myanmar and Bangladesh. The tribunal gave the island no effect on the EEZ and continental shelf boundary. Source: Watson, 2015

Regrettably, it can be said that the tribunal's achievement in attracting this comparatively low-stakes case might truly discourage larger powers' willingness to come into its judgment. ITLOS has no longer been a blank slate onto which both parties can anticipate their hope for results. Its verdicts on maritime border disputes, along with those of other bodies, have developed into a recognized body of jurisprudence on the issue. Parties to disputes gradually have at least a common idea of what the result of their case might be, and they are unlikely to come into trial, if they might not like the outcome of judgment (Watson, 2015). However, this notion has been proven through the judgment of ITOLS on Bangladesh-Myanmar maritime dispute.

\section{Exploration of Oil and Gas in the Bay of Bengal}

Myanmar demanded the application of the equidistance principle for delimitation, while Bangladesh always sought to delimit its maritime boundary on the basis of the application of the equitable distance. It was anticipated that the delimitation of the maritime boundary on the basis of the equidistance principle would result in the annexation of much of the sea area of Bangladesh by Myanmar. Bangladesh would get a tiny share in the Bay of Bengal, and it would be virtually cut off from accessing high sea if it was delimited on the basis of equidistance principle. The tribunal applied the equitable principle instead of equidistance to solve the dispute (Faruque, 2013). 
In the conclusion, the tribunal took the decision quite accurately. It changed the boundary that would have resulted in the equidistance approach in order to evade cutting off Bangladesh from the surface reaches of its EEZ. The subsequent line was almost at the center of the borders offered by Bangladesh and Myanmar (Watson, 2015).

The decision was remarkable in part for the court's judgment that it had power to decide not only in contending for rights to waters but also the continental shelf. It also has right to the creation of a "grey area" which is on Bangladesh's side of the boundary line drawn by the tribunal but in the possible 200-nautical-mile EEZ of Myanmar. Furthermore, similar grey areas have since been created by other tribunal bodies, which comprises of the Permanent Court of Arbitration's in July 2014 providing judgment on the India-Bangladesh maritime boundary dispute. The grey area is the outcome of the tribunal's decision for an equitable resolution of the dispute (Watson, 2015).

After the tribunal's verdict, Bangladesh would be able to explore oil and gas in the Bay of Bengal, where a huge amount of reserves are expected to be in existence. Also, geologists and international oil companies are optimistic that Bangladesh is literally floating on gas. Whatever the onshore prospects are, no one denies that the real deal lies in the Bay of Bengal. The prospects of finding mineral deposits in the bay is very clear when one sees that not only India but also Myanmar recently discovered 100 trillion cubic feet and 7 trillion cubic feet of natural gas respectively in their deep sea blocks. India's reliance industries (a business conglomerate in India) have already begun production from the deep sea blocks in the bay and are expected to double India's natural gas output. Myanmar, on the other hand, has allowed China, South Korea, and India to invest billions of dollars in producing gas from deep sea basins (Uddin \& Ahamed, 2011). However, Bangladesh can now explore its natural resources from the deep sea of the Bay of Bengal based on the verdict of ITOLS. 


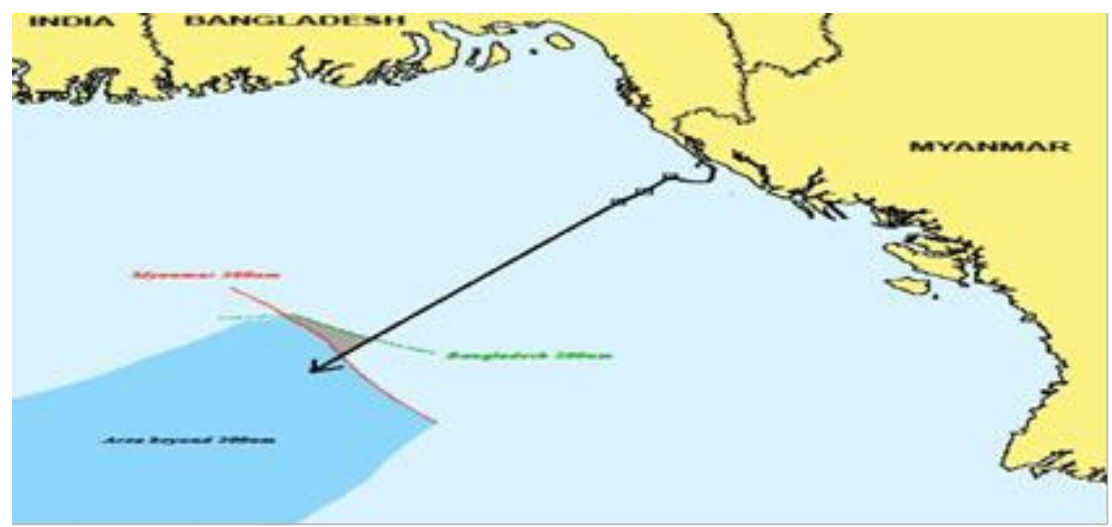

Figure 5: Much larger section of its own continental shelf Source: Watson (2015)

\section{Drug Trafficking along the Bangladesh-Myanmar Border}

A huge number of people in Ukhia and Teknaf sub-districts are actively involved in yaaba trade through which they have already become millionaires. The yaaba business is also very popular among the young generation in Bangladesh, particularly the uneducated and less-educated people. Also, the people who have been involved in yaaba trade are now becoming millionaires swiftly. Apart from the people of Cox's Bazar, a huge number of people from other districts of Bangladesh have been conducting yaaba trade. They have also been supplying the tablets to most districts of the country, including the Chittagong and Dhaka cities, for high demand and huge profit with the support and cooperation of the law enforcement agencies (particularly the police force). The law enforcement agencies are the main perpetrators of yaaba trade in Bangladesh, and they are the real beneficiaries of yaaba trade. They use yaaba trade and yaaba dealers as a means to make money. The police force are involved in kidnapping, cross-firing, persecution, and filing of false cases against many innocent people, and yaaba is used as a tool through which they can easily demand ransom. In the name of combating yaaba trade, the police force looted the houses of many people and arrested the house owners who were later killed by the police without bringing them to justice. The police also took huge amount of money as bribe for releasing the arrested people. Many members of the law enforcing agencies have now become millionaires by involving themselves with yaaba trade. Also, they perform offensive operation against many criminals and innocent people, where the arrested people have been compelled to provide huge sum of money to the police (Field Survey in Ukhia and Teknaf in 2020).

Almost all the people of Bangladesh are now demanding investigation into the unlawful killings of innocent people and some yaaba dealers by police, and fair trials for those who have been responsible in criminal activities such 
as looting of cash money, gold, and different ornaments from the different houses. They are also responsible for arresting many people without warrants of arrests and killing them in the name of encounter. They also control the yaaba trade along the Bangladesh-Myanmar border and throughout the country. Most of the time, the police seize yaaba drugs from the yaaba dealers.

Thereafter, the seized yaaba drugs are sold out in the black markets by the police force, where they get enormous money. This is why yaaba trade has not been stopped in the country. Law enforcement agencies are using some people to operate the yaaba business. However, after collecting a huge amount of money from them, some have been killed by the law enforcing agencies on the ground of their yaaba trade. Apart from the Police, Rapid Action Battalion (RAB), Border Guards Bangladesh (BGB) and Coast Guards are somehow involved in the trade. Around 250 people were killed up until now (DBC News, 2020). Apart from the law enforcing agencies, some administrative agencies and leaders of different political parties are also beneficiaries of yaaba trade in Bangladesh. Some innocent people have been arrested, and they have been entangled with false cases of yaaba in order to request for ransom. If they fail to provide the demanded money, they are killed in the drama of cross-fire. The police also demand ransom from different businessmen, land owners, and different professionals by arresting and keeping them in police custody. Many police officers have now been arrested and put in jail for their crimes of extra-judicial killings, for ransacking many houses, and for demanding ransom from criminals as well as innocent people. There are many examples that show that, after taking huge amount of bribes from the arrested people as ransom, the arrested people have been killed instead of getting released from the police custody. This is a crime against humanity and gross human rights violations (Field Survey in Ukhia and Teknaf in 2020).

However, the use of yaaba is very harmful to the human body. The long term effect of the use of yaaba is dangerous. Despite knowing the negative effect of yaaba, the law enforcement agencies are, sometimes, silent and refrain from arresting and detaining the yaaba dealers. This is because a huge number of them are directly involved in the yaaba trade in many ways. They also usually accept a huge amount of bribes from yaaba dealers (Rashid, Ahamed \& Rahman, 2020).

Furthermore, some local political leaders are also involved in some ways with this unethical trade of yaaba and some of them have become millionaires as well. Therefore, the government of Bangladesh should combat the yaaba dealings for the greater interest of the nation. According to the field survey, many people of this area are involved in these illegal trades such as yaaba trade, arms trade, sending the Rohingya people to Middle East and Malaysia by providing them with the Bangladeshi passports unlawfully, and evading the taxes of Bangladesh customs while dealing with the exports and 
imports business in Bangladesh-Myanmar border. It has become a very complex issue for the government of Bangladesh to control these verities of crimes.

\section{Cross Border Tension, Crime, and Terrorism}

A local Awami League (the largest political party in Bangladesh) leader, President of Thaing Khali High School and Rahamater Bill Government Primary School, Mr. Altaz Ahamed, whose home is adjacent to both the greater Thaing Khali Rohingya refugee camp and BangladeshMyanmar border, has explained that they have been living continuously at the danger of being attacked by both the Rohingya refugees and the military of Myanmar. He further stated that "If any tension and instability arises between Bangladesh and Myanmar in the border area, we cannot carry on our regular works, agrarian activities, and fishing in the border area in the distress of being attacked by armed forces of both countries. At that emergency situation, the Rohingya rebellion groups also may come out and involve themselves in the large-scale organized crimes" (Rashid, Ahamed \& Rahman, 2020).

Mr. Altaz Ahamed has further warned about the spread of blackmoney earned through yaaba trade, which may be used for border terrorism and political instability in the region. Yaaba traders of Ukhia and Teknaf have already created several problems like posing threat to the law and order situation. There are many examples of cross-fires between yaaba traders and law enforcement agencies, where a huge number of drug dealers died. Social disorder has also been observed such as purchasing of lands and vehicles by yaaba traders, constructions of new buildings, cutting down hills and trees, deterioration of law and order situation, land grabbing, and different establishments by yaaba traders. In the society of Teknaf and Ukhia, there is a huge social dissatisfaction over the issue of black money earned through yaaba trade which has jeopardized the entire youth society of Bangladesh both physically and mentally. In addition, a section of law enforcement agencies is also involved in the trade. For example, when they arrest the criminals, they are later released on bribes. Sometimes, the captured yaaba tablets are sold in the black markets by the police force through which many of them have become millionaires. Many members of the law enforcing agencies also try to lobby at higher level to get posted in Ukhia and Teknaf since they benefited financially. The rule of law and good governance are quite absent in Uhkia and Teknaf pertaining to the combating of yaaba trade.

The Arakan Rohingya Salvation Army (ARSA) is an insurgency group. However, according to ARSA's statement, they are freedom fighters for the state of Rakhine from Myanmar. They carried out an attack on Myanmar's security posts in 2017 which caused the armed forces' brutal "clearance operations," in the state of Rakhine. The ARSA and Myanmar's 
security forces are committed to carry out more attacks in the region. Bangladesh is apprehensive that ARSA will try to recruit interested Rohingyas from the refugee camps, and the camps can be used as a base for cross-border fighting (Alam, 2018).

Is ARSA therefore linked to other regional or international terrorist organizations? This is not clear yet. Al-Qaeda in the sub-continent issued a declaration where they invited Bangladesh's Muslims to provide support to the Rohingyas. It is not very clear whether the Al-Qaeda has a link with ARSA or not. Nevertheless, extremist networks in Bangladesh and Burma exist through which the ARSA, and Buddhists extremist are gaining influence in the region to a large extent (Alam, 2018). The table below shows the crime statistics for the last 7 months (November, 2014 - May, 2015) in the Bangladesh-Myanmar border.

Table 1. Crime Statistics at Bangladesh Myanmar Border

\begin{tabular}{cccccc}
\hline $\begin{array}{l}\text { Year } \\
\text { 2014-2015 }\end{array}$ & $\begin{array}{c}\text { Human } \\
\text { Trafficking }\end{array}$ & $\begin{array}{c}\text { Drug } \\
\text { Trafficking }\end{array}$ & & Smuggling & \multicolumn{1}{c}{$\begin{array}{c}\text { Illegal } \\
\text { Entrance }\end{array}$} \\
\cline { 1 - 2 } \cline { 5 - 6 } November, 2014 & 14 & 28 & 6 & 5 \\
December, 2015 & 10 & 24 & 2 & 5 \\
January, 2015 & 10 & 45 & 1 & 9 \\
February, 2015 & Nil & 33 & 4 & Nil \\
March, 2015 & 6 & 29 & 1 & 3 \\
April, 2015 & 7 & 31 & 2 & 9 \\
May, 2015 & 14 & 22 & 4 & 4 \\
\hline
\end{tabular}

Source: Teknaf Police Station, Cox's Bazar, Bangladesh, (Also cited in Rashid, Ahamed \& Rahman, 2020)

\section{Trade, Investment, Exports, and Imports between the Two Countries}

Mr. Abul Hassan Mahmood Ali, former Foreign Minister said that "Bangladesh has been enjoying the geopolitical and geo-strategic advantages located at the connecting point among South and Southeast Asian countries for trade and navigation. Bangladesh should therefore take some steps to transform its geo-strategic position into geo-economic chances. As a geographic link between the two regions, South Asia and South East Asia, BIMSTEC can take the necessary steps to achieve that goal. Under the aegis of BIMSTEC, there is need to also focus on important areas such as poverty alleviation, climate change, agriculture, health, technology, counter-terrorism and transnational crime, cultural cooperation, and tourism. Opportunity of Investment is enormous since Myanmar has opened its market to the rest of the world, and like other countries, the businesspersons in Bangladesh are getting prepared to invest millions of dollars in Myanmar (Alam, 2017).

A good number of businesspersons in Bangladesh, under the banner of Bangladesh-Myanmar Chamber of Commerce and Industry (BMCCI) and the Bangladesh Myanmar Business Promotion Council (BMBPC), have already 
started investing in various sectors of both countries. The government of Bangladesh is also patronizing the rising entrepreneurs who desire to carry out trade with Myanmar. The banking sector of Bangladesh also gives loans and advice to the rising entrepreneurs of Bangladesh. BMBPC Chairman, Syed Mahmudul Huq, in an interview said that "there are huge opportunities to invest in Myanmar's different service sector including information technology, telecom, tourism, fish and aquaculture, aviation, and agro-based industry. These sectors are very attractive to business persons in Bangladesh, and they are trying to control these sectors before anyone gets involved. He further described that "Bangladesh has an opportunity to benefit from the contract agricultural activities in Myanmar, and it will be very helpful for Bangladesh to meet its demand since the unfledged farming country is going to extend the land tenancy term to 70 years from the current 30 years" (Alam, 2017).

This is a golden opportunity for the businesspersons in Bangladesh, and there is hope that the obstacles would not obstruct this process of cooperation. On the other hand, Bangladesh has become a great potential of foreign investment in recent times. Also, it has been termed as 'good economic future' by World Bank for Bangladesh. It is good news for Bangladesh that the country scores well in terms of socio-economic indicators of human development. Multi-national institutions and global banks have very high outlook about the development index of Bangladesh. JP Morgan, Citi, Merrill lynch, and Goldman Sachs have acknowledged Bangladesh as one of the main hubs for trade and investment opportunity. There are various sectors in Bangladesh that need investment such as infrastructure, technology, industry, and communication.

The possibility of Bangladesh building cooperative relations with Myanmar creates huge sources of imports and exports opportunity with Myanmar. The statistics show that in fiscal year 2012-2013, Bangladesh exported goods worth \$13.67 million to Myanmar and imported goods of \$484 million from there. The amount of exported goods of Bangladesh is lower than the amount of Myanmar. Therefore, for the balance of trade between the two countries, it is imperative for Bangladesh to seek the market to export more goods in the future. The goods that are major exports of Bangladesh to Myanmar are frozen food, agro-products, chemical products, leather, jute goods, knitwear, woven garments, rice, fish, and timber. On the other hand, Bangladesh imports live animals, vegetable products, prepared foodstuffs, beverages, tobacco, plastics, raw hides and skin, leather, wood and articles of woods, footwear, textiles, and article of human hair (Alam, 2017).

Apart from the above mentioned products, fuel (kerosene), food oil, birth control pills, and essential medicines for treatment are illegally smuggled into Myanmar from Bangladesh through which the revenue collection of 
Bangladesh is evaded. If these smuggling of different products are monitored strictly in the border and are legalized, both countries will benefit economically. Moreover, some drugs, yaaba, clothes, Chinese and Thai toys, Burmese shoes, towels, lungi, and ladies' items are smuggled into Bangladesh from Myanmar where smugglers of both countries are involved in this kind of illegal trade (Field Survey, 2020).

However, in 2010, at a meeting of Joint Trade Commission (JTC), the two neighbors decided to raise annual bilateral trade from $\$ 100$ million to $\$ 500$ million. In the meeting, other issues were discussed including expansion of border trade, cooperation in various sectors including agriculture, food, fisheries, power and mineral resources, and introduction of direct shipping services between the two nations to increase trade. These are the signs that show the rising cooperative relations between Bangladesh and Myanmar. There are also some important areas of economic cooperation such as investment in Myanmar and Bangladesh, tourism, teak wood, cane, marine fishing, prawn farming, livestock breeding, construction, motels, ceramic pottery, manufacturing, rubies/sapphire/jade/pearls polishing, etc. It is evident that Bangladesh is deeply interested to make a deal about trading with Myanmar (Alam, 2017).

\section{Comparison of the Economic Strength of Bangladesh and Myanmar}

The economy of Bangladesh is a rapidly growing market economy. It is the 39th largest economy in the world in the nominal terms of GDP, and the 30th largest by purchasing power parity. It is also classified among the Next Eleven (11) fastest growing market middle income countries. According to the IMF data, in 2019, Bangladesh was the world's seventh rapidly growing economy with a rate of 7.3\% GDP annual growth (IMF, 2019). Dhaka stock exchange and Chittagong stock exchange is the main financial and trade centers of the country, and the financial sector of Bangladesh is now the second largest in the South Asian countries. Since 2004, Bangladesh has been able to maintain a GDP growth of $6.5 \%$ due to its exports of garments' products, remittances, and the national agricultural sector.

It has followed export-oriented industrialization, and its main export sectors comprises of textiles, fish and seafood, shipbuilding, jute and leather goods. It has also established self-reliant industries in pharmaceuticals sector, steel and food processing. The cable industry of Bangladesh has witnessed rapid progress over the years, which has received high investments from many foreign companies. Also, Bangladesh has considerable reserves of natural gas. Presently, it is Asia's seventh biggest gas producer. Offshore gas exploration activities are growing in its maritime zone in the Bay of Bengal and adjacent areas. It also has huge deposits of limestone (The Daily Star, 4 June 2012). The government of Bangladesh highly promotes the Digital 
Bangladesh project as part of its strong determination to develop the country's fastest growing information technology sector.

The below table shows the economic strength of Bangladesh in terms of GDP purchasing power parity, per capita income, and nominal GDP. It shows that the per capita income of Bangladesh is US \$ 2173 Dollar.

Table 1. The economic performance of Bangladesh

\begin{tabular}{|c|c|}
\hline \multicolumn{2}{|c|}{ Population } \\
\hline 2018 estimate & $161,376,708(8 \mathrm{th})$ \\
2011 census & $149,772,364(8 \mathrm{th})$ \\
Density & $1,106 / \mathrm{km}^{2}(2,864.5 / \mathrm{sq} \mathrm{mi})(7 \mathrm{th})$ \\
\hline GDP (PPP) & 2020 estimate \\
Total & $\$ 917.805$ billion $(29$ th $)$ \\
Per capita & $\$ 5,453(136$ th $)$ \\
\hline GDP (nominal) & 2020 estimate \\
Total & $\$ 347.991$ billion (39th) \\
Per capita & $\$ 2,173(143$ th) \\
\hline
\end{tabular}

Source: The Financial Express, June (2020), https://en.wikipedia.org/wiki/Bangladesh

On the other hand, the economy of Myanmar is an evolving economy and its nominal GDP was $\$ 69.322$ billion in 2017 , and an estimated purchasing power parity (PPP) GDP of \$327.629 billion in the fiscal year of 2017 (World Bank, 2017). For the 2019 fiscal year, it was assumed that the GDP per capita in Myanmar will be around \$6,509 in terms of purchasing power parity per capita and $\$ 1,490$ in terms of nominal per capita.

Table 2. The economic performance of Myanmar

\begin{tabular}{|c|c|}
\hline GDP & $\$ 65.994$ billion (nominal, 2019) \\
& $\$ 355.609$ billion (PPP, 2019) \\
\hline GDP rank & 73rd (nominal, 2019) \\
& 50 th (PPP, 2019) \\
\hline GDP growth & $6.8 \%(2018) 6.3 \%(2019)$ \\
& $1.5 \%(2020 \mathrm{f}) 6.0 \%(2021)$ \\
\hline GDP per capita & $\$ 1,245($ nominal, 2019) \\
& $\$ 6,707(\mathrm{PPP}, 2019)$ \\
\hline GDP per capita rank & 156 th (nominal, 2019) \\
& 127 th (PPP, 2019) \\
\hline GDP by sector & agriculture: $24.1 \%$ \\
& industry: $35.6 \%$ \\
& services: $40.3 \%$ \\
\hline
\end{tabular}

Source: Economy of Myanmar, (23 January, 2017). Ministry of Commerce, Doingbusiness.org, https://en.wikipedia.org/wiki/Economy_of_Myanmar

However, foreign investment has been invigorated. This is because it has accomplished only modest achievement. More so, foreign investors have been put at risk by the plans of the military government. Also, the USA has imposed trade sanctions on Burmese government. Furthermore, the European Union has imposed bans on arms, non-humanitarian aid, visa sanctions on 
military leaders, and restricted foreign investments. The US and the European Union have also imposed embargoes on account of the persecution of the Rohingya ethnic minorities and military operations in the country. Many countries in South Asia, South East, and North East Asia such as India, China, and Thailand have enthusiastically continued trading with Burma (Justin, 2013; Justin, 2013).

However, it is evident that the economy of Bangladesh is several times higher than that of the economy of Myanmar and is making tremendous progress. However, the economy of Myanmar could have been in a better position because of her natural resources and the huge geographical size, with a long coastal belt having access to both Bay of Bengal and Indian Ocean. Economic embargoes and military rule have undermined its economy substantially. Many scholars think that in order to lift economic embargoes imposed upon it, change is required in the political system of Myanmar. This is transition from authoritarian military rule into democratic rule with direct elections in the country, even though the democratic political system is parliamentary or presidential. Ethnic clashes are also a big problem for the economy of Myanmar to grow in the right direction. It should follow the path of inclusiveness in its political system to ensure equal rights for all ethnic groups irrespective of caste, creed, and religion. Political inclusiveness of all ethnic groups plays an important role in the economic progress of a country. It is important for Myanmar to take the necessary steps to recognize all of its ethnic groups, including the Rohingyas, which can be used as tool for economic development and political legitimacy.

\section{Comparison of the Military Strength of Bangladesh and Myanmar}

Myanmar is a relatively robust country according to its military capabilities. They have approximately 500,000 military personnel, who are well-equipped with up to date weapons and ammunitions. They are able to carry out any kind of military operation in the neighboring country. The country also has strong military relations with China, and this has a crucial effect. Myanmar's military junta has received vast supplies of arms, ammunitions, and other fighting hardware from China from the time when they signed two different defense cooperation contracts in 1990 and 1994. China had provided US\$ 2.2 to 2.5 billion value of arms and other military hardware to Myanmar's government, which comprises of artillery tanks, pieces, Armored Personnel Carriers (APC), trucks, high speed jet fighters, naval vessels, etc. (Patwary, 2019).

Moreover, Myanmar has developed its relationship with communist country, North Korea, which is governed by a dictatorial and authoritarian rule. According to the report of November 2008, Commander-in-Chief of the Myanmar's Armed Forces paid a visit to North Korea to procure the 
technology for constructing tunnels, airplane, marine ships and artilleries, which will be able to reach 500-1,000 kilometers. There is also a report that North Korea is helping Myanmar to build a secret nuclear reactor and plutonium extraction plant that will help to produce an atomic bomb within five years (Patwary, 2019).

Compared to the Myanmar's military strength, it can be said that Bangladesh's military power is not weak, but has less military equipment and personnel. In terms of army, navy and air force, the government of Bangladesh has to recruit fresh soldiers to make a balance with the military strengths of Myanmar. Bangladesh needs to prepare itself militarily to protect itself, if any armed conflict arises between the two countries.

\section{China's Geopolitical Interests and Bangladesh-Myanmar Relations}

China is very active in Myanmar's geopolitics and economic development. As part of China's regional connectivity and infrastructural development, it has taken many steps. In February 2012, officials from the four countries approved the road map of developing the 2,800km highway from Kolkata to Kunming through Bangladesh, Northeast India, and Myanmar. Thus, this would be the first expressway connecting China and Southeast Asia to South Asia (Rahmatullah, 2013; Islam, Ailian \& Jie, 2018).

In September 2013, Chinese President Xi Jinping proposed the grand new vision of the Belt and Road Initiative (BRI), which promotes Eurasian connectivity, and it further includes the road map for the BCIM Economic Corridor (BCIM-EC). The BCIM-EC is planned to extend on three routes: one, known as $\mathrm{K} 2 \mathrm{~K}$, will run from Kunming to Kolkata via Myanmar, Northeast India and Bangladesh; the other two will go from Mandalay to Chittagong in one direction, and to Sittwe seaport in Rakhine in another direction. It is firmly believed that with the connectivity of transports, energy and telecommunications networks, it will play a key role in economic development for the entire region (Uberoi, 2016; Islam, Ailian \& Jie, 2018). It is also true that China has invested a huge amount of money in oil, gas, high ways, special economic zone, infrastructural development, power plantation, and deep sea ports in Myanmar. The country has strong military relationship with Myanmar. In terms of exports and imports, Myanmar is heavily dependent on China such that its $40 \%$ trade of total trades is accomplished with China. China is largely benefiting from the Myanmar's gas pipelines, connectivity, trade, and seaports. Therefore, it can be said that China has strong geopolitical and economic interests in Myanmar.

\section{India's Geopolitical Interests and Bangladesh-Myanmar Relations}

Just like China, India is also actively involved in the geopolitics and economic development projects in Myanmar. It has also taken many 
policies and decisions to connect with Myanmar and South East Asian nations. Geopolitics of India is another significant reason for building cooperative relations with Myanmar. If we discuss it with more elaboration, we will find the India factor of Bangladesh-Myanmar relations (Alam, 2017).

The reality is that Bangladesh is surrounded by India and for that, it has some troubles or issues with India. Being a smaller state to regional power India, Bangladesh has to compromise or face the reality of geo-politics. Bangladesh wants to maintain an amicable relation with India. So building cooperative relations with Myanmar and through this "Look East" policy will bring tough competition against Indian dominance over Bangladesh. Analysts of Bangladesh advocate finding alternatives to SAARC. Myanmar's membership of the ASEAN has great significance for Bangladesh that Myanmar can take a step for incorporating Bangladesh in the ASEAN, which will unfold new opportunities for Bangladesh (Alam, 2017).

In addition, there is a fruitful opportunity for Bangladesh as Myanmar and Thailand have supported Bangladesh's initiative for ASEAN membership. Hence, Bangladesh should exploit this opportunity by establishing close relations with Myanmar. Bangladesh and Myanmar being a member of SAARC and ASEAN respectively can act as bridging partner of two regions and economies. In ASEAN's past calculations, South Asia including Bangladesh was not featured as a priority area. Nevertheless, the situation may now be changing as ASEAN currently seems to look westward, while South Asia itself looks eastward. Former Foreign Minister of Bangladesh, Mr. Abul Hassan Mahmood Ali, expressed his regards about ASEAN on the occasion of the 48th Anniversary of the founding of ASEAN on 8th August 2015 at the Royal Thai Embassy in Dhaka: "Bangladesh has always tried to maintain very sociable relations with its nearby neighbors and the South East Asian Countries. In fact, Bangladesh acts as bridge between South Asia and South East Asia. Bangladesh has established its resident missions in almost all the ASEAN countries" (Alam, 2017).

However, India has huge geopolitical and economic interests in Myanmar. For instance, it has invested a huge amount of money in power plantation projects, in oil and gas, roads, and highways construction along with the constructions of deep sea ports and bridges in Myanmar. Therefore, in any critical situation, India does not support Bangladesh. In the recent crisis of the relationship with Myanmar, India has sided with Myanmar considering her trade and investment, economic and geopolitical interests. Furthermore, India desires to be closely linked with Myanmar to combat insurgencies in North East India bordering Myanmar and China. Also, Myanmar's Rakhine state is connected with the Bay of Bengal and Indian Ocean through which Indian navigation and supply of exports and imports are being greatly benefitted. 


\section{International Outlook of the Bangladesh-Myanmar Relations}

In any conflict between Bangladesh and Myanmar, the US is expected to side with Bangladesh because both nations share democratic values, support for regional and global stability, human rights, security, and peace. In addition, both countries are staunchest critics of terrorism. The US has been one of the staunchest critics of Myanmar's military junta due to its lack of honor for human rights and democracy. The US has already imposed economic and arms embargo on Myanmar and it has persuaded its western allies to do the same to put pressure on the military junta to restore democracy in the country (Uddin \& Ahamed, 2011).

So, in any conflict, Bangladesh can expect to find the U.S on its side, while Myanmar may even be more isolated for attacking a democratic country, Bangladesh. Britain and France will probably join the U.S in support of Bangladesh in a fight against Myanmar for the same reason. Russia, which is one of the few nations that provided diplomatic support to the independence movement of Bangladesh, which has a strong military relation with Myanmar, may possibly find herself in a hard political situation. Hence, it may present itself as a peace dealer to uphold neutrality in any future battle between Myanmar and Bangladesh. Despite the bitter memories of 1971, Pakistan acknowledges the strategic significance of Bangladesh's geographic location. Bangladesh could expect to get moral and even some logistic support from the Arab nations in a possible future conflict. Oppression of the Muslim Rohingyas by Buddhists Myanmar junta has drawn the attention of the Muslim as well as the western world, which may provide their support to Bangladesh, if there emerges any conflicts between Bangladesh and Myanmar (Uddin \& Ahamed, 2011).

\section{Policy Recommendations for Bangladesh and Myanmar}

It is important to note that in relation to dispute between Bangladesh and Myanmar, Bangladesh is the affected one. So, some past as well as recent developments, like the disputes over exploration of gas, the building of a barbed wire-fence by Myanmar along the common border between the two countries without consulting with Bangladesh, and the fresh influx of Rohingyas into Bangladesh -which has been discussed above- are not a matter of little concern for Bangladesh. Rather, they create new tensions and appear as threat for Bangladesh. The steps taken by Myanmar as discussed earlier are certainly not of a defensive type, but some would rather say they show aggressive intension. Bangladesh needs to exercise caution and should adopt subtle diplomacy as some international political analysts stated that Myanmar's pacifist intension cannot be trusted. Their ethnic cleansing of Rohingyas is comparable to the ethnic cleansing of Bosnia and Herzegovina by the Serbs. Myanmar is one of the bastions of authoritarian governance in 
the world today, and it has the largest military in South East Asia (Uddin \& Ahamed, 2011).

Keeping in line with its foreign policy, Bangladesh should take the first step diplomatically. As there exist a gap in terms of values between Bangladesh and Myanmar, peaceful negotiation would be the best possible to resolve the dispute and reduce the tension between the two countries. Bangladesh should go to the international community and regional organizations. It can raise the Rohingya issue to the UNHCR. Random access and visits by the high profile negotiators can be a path to peace. Bangladesh government must take determined steps to bring illegal trade and arms trafficking under control. Yaaba smuggling should be stopped, and necessary steps must be taken to stop producing and supplying yaaba drugs to Bangladesh by Myanmar. Bangladesh should strengthen economic relations with Myanmar and improve security measures based on a strong economy (Uddin \& Ahamed, 2011).

Besides, Myanmar should take back all the Rohingyas from Bangladesh, and constitutionally approve them with their citizenship rights. It should stop selling arms to the insurgents of Chittagong hill tracts. Myanmar should not go for the exploration of oil and gas within the Bangladesh's territories and maritime boundary. It must stop flexing military muscle against Bangladesh (Uddin \& Ahamed, 2011). Both countries should come ahead to invigorate trade relations so as to strengthen cooperation in terms of economic, political, and cultural aspects through which future conflict may be definitely avoided between the two countries.

\section{Conclusion}

Bangladesh always wants to maintain friendly relations with its neighboring countries including Myanmar, but Myanmar is not very interested in maintaining friendly relations with some of its neighbors including Bangladesh. Sometimes, Myanmar poses threats to Bangladesh along the border area in many military ways. Therefore, Bangladesh needs to develop its military power on one hand, and also try to maintain friendly relations with Myanmar on the other hand so as to ensure strategic balance between the two countries. However, the country's relations with its eastern neighbors still remain insecure and the newest developments are really worrying. Our policy makers should remember the axiom that diplomacy is a helpless orphan unless backed by force. For this reason, existing defense priorities must be reviewed to suit the magnitude of threat being faced by the nation (Patwary, 2019). Bangladesh should come forward to transform her detached neighbor into a close neighbor. Finally, Bangladesh has to move forward to pursue its geopolitical goals to ensure optimum gains for the sake of national security. The country has no time to think more. It is time to act seriously as the country 
is far behind in the race of strategic military balance with Myanmar (Patwary, 2019).

India should help Bangladesh because it practices democratic beliefs like India. As an emerging super power, China should play a positive role as both Bangladesh and Myanmar have good relationship with both India and China. Moreover, Russia, Japan, South Korea, and Association of South East Asian Nations (ASEAN) can create pressure on Myanmar to take back the Rohingyas, who are a big burden on Bangladesh. All NGOs, local and International, must put an end to providing illegal and unethical supports to the Rohingya groups who are playing a negative role in the repatriation process. Long term peace, stability, and development are more important than short term economic benefits. Bangladesh government should restrict the activities of NGOs inside the refugee camps and around the camps. Otherwise, they will put serious barriers to the Rohingya repatriation process for their greater politico-economic interests. After all, security, stability, and development with environmental protection are a must for Bangladesh than the interests of NGOs and the Rohingyas. Therefore, the NGOs should be involved in the development of infrastructure in Ukhia and Teknaf, while the Bangladesh government should provide them with necessary assistance and cooperation. Geo-strategically, Ukhia and Teknaf are very important for trade and investment, regional connectivity, and deep seaports. Also, there is huge reserve of oil and gas in the Bay of Bengal along the coastal belt of Ukhia and Teknaf (longest sea beach of the world is located here), huge marine resources, the Bay of Bengal, which is connected with Indian Ocean. Also, it is a connecting point to North East India, Myanmar, South East Asia, and China. Therefore, the government of Bangladesh should focus on Ukhia and Teknaf in terms of infrastructural development.

\section{Acknowledgement}

We hereby acknowledge the input of every member of this team for their tireless efforts during this work. The first and second authors of this study, Akkas Ahamed and Mohammad Alam Chowdhury (Associate Professors), were involved as Research Associate in a Research project titled "Bangladesh and Its Borders: A Study of Cross Border Issues". The Research Project was directed by Professor Dr. Bhuian Md. Monoar Kabir of the Political Science Department at the University of Chittagong in Bangladesh. They surveyed and collected the primary information on geopolitical and economic issues in the districts of Cox's Bazar and Bandarban in Bangladesh bordering with Myanmar. The third author of this study, Md. Sayedur Rahman, carried out an empirical research on Bangladesh-India border relations and he published a research article on border economy in an international journal. Thus, he has been able to 
contribute to this paper through his acquired knowledge on border land studies. The writers of this research paper are grateful to the Research project which helps in the data collection process.

\section{References:}

1. Alam, A. M. S. (2017). Bangladesh Myanmar Interplay Prosperity: Prospects \& Challenges, Peace and Security Review Vol. 8, No. 16, First Quarter, 2017, pp-43-45

2. Alam, M. (2018). How the Rohingya crisis is affecting Bangladesh, and why it matters, An Analysis by Monkey Cage, The Washington Post, https://www.washingtonpost.com/news/monkeycage/wp/2018/02/12/how-the-rohingya-crisis-is-affectingbangladesh-and-why-it-matters/

3. Ahmad, B.G.S. ndc, psc, (retd) (2017). Foreign Policy of Myanmar, Peace and Security Review Vol. 8, No. 16, First Quarter, 2017, p.1-17

4. Ahmed, K. M. (September 2008). Bangladesh and its Neighbors, Asiatic society Bangladesh, p.96.

5. Chow, J. T. \& Easley, L. E. (2016). 'Myanmar's Foreign Policy Rebalance" The Diplomat, 10 September, http://thediplomat.com/2016/09/myanmars-foreignpolicy-rebalance/, 24/4/17

6. Dai, Y. \& Hongchao, L. (2014). "Rivalry and Cooperation: A New "Great Game" in Myanmar," Asia Paper, December 2014, Institute for Security and Development Policy, Västra Finn Bodavägen 2, 13130 Stockholm-Nacka, Sweden, www.isdp, p-5.

7. DBC News (2020). Bangladesh

8. Economy of Myanmar (23 Janury, 2017). Ministry of Commerce, Doingbusiness.org, https://en.wikipedia.org/wiki/Economy_of_Myanmar

9. Faruque, A. A. (2013). International Tribunal of the law of the sea (ITOLS) Judgment on the Bangladesh-Myanmar Maritime Boundary Demarcation, in Bhuian Md. Monoar Kabir (ed.) Sino-South Asian Relations: Continuity and Change, Department of Political Science, University of Chittagong, January, 2013, pp.137-157.

10. Islam, M. S., Ailian, H. \& Jie, Z. (2018). World Century Publishing Corporation and Shanghai Institutes for International Studies China Quarterly of International Strategic Studies (2018), Vol. 4, No. 4, 613629

11. International Monetary Fund (3 October 2019). "Real GDP Growth: Annual Percent Change". imf. Org. 
12. Justin, C. (24 April 2013). "End of EU sanctions augurs Myanmar rush". Inside Investor.

13. Justin, C. (29 April 2013). "US to boost Myanmar trade, investment". Inside Investor.

14. Maung, D. H. Ambassador (Rted) (April, 2016). "Recent Economic Development of Myanmar."

15. Patwary, O. H. (2019). Bangladesh-Myanmar Relations: The Security Dimension, Bangladesh Institute of Peace and Security Studies, (BIPSS),

Dhakahttps://www.researchgate.net/publication/335970554_Banglad esh_-Myanmar_Relations_The_Security_Dimension

16. Reuters (March 18, 2017). "China, Russia block U.N. council concern about Myanmar violence” http://www.reuters.com/article/usmyanmar-rohingya-un-idUSKBN16O2J6

17. Rahmatullah, M. (February, 23-24, 2013). "Strengthening Connectivity among BCIM Countries," Presentation at the Eleventh BCIM Forum, Centre for Policy Dialogue, Dhaka, http://www.cpd.org.bd/11BCIM/PapersSession\%20IIStrengthening\% Multimodal \%20Connectivity/M\%20Rahmatullah.pdf.

18. Rashid, B. H. U. (11 ${ }^{\text {th }}$ January, 2019). Bangladesh-Myanmar relations: An Overview, vol. 35, issue, 27, Dhaka

19. Rashid, M.H. O., Ahamed, A., \& Rahman, M. S. (July 2020). A Critical Study on the Transnational Organized Crime along the Bangladesh-Myanmar Border" in International Journal of Sciences: Basic and Applied Research (IJSBAR) 52(2):203-216

20. Selth, A. (May 2001). "Burma: A Strategic Perspective," Working Paper \#13, Strategic and Defense Studies Center, Australian National University, $\mathrm{p}-.5$

21. Sein, U. T. (2016). President of Myanmar, excerpts from his inaugural speech and address to the UN General Assembly, quoted in Myoe, Maung Aung, "Myanmar's Foreign Policy under USDP Government: Continuities and Changes" in Journal of Current Southeast Asian Affairs, 35,1, $129-130$

22. The Financial Express (13 July 2013). "Sub-regional connectivity in South Asia: Prospects and challenges".

23. The Daily Star (4 June 2012). "Largest limestone reserve discovered".

24. Uddin, M. K. \& Ahamed, A. (May, 2011). Bangladesh-Myanmar relations: continuity and change, The Chittagong University Journal of Social Sciences, Vol. 26, pp. 79-98.

25. Uberoi, P. (2016). "Problems and Prospects of BCIM Economic Corridor," China Report, Vol. 52, No. 1 pp. 19-44. 
26. Watson, S. (2015). The Bangladesh-Myanmar Maritime Dispute: Lessons for Peaceful Solutions, Asia Maritime Transparency Initiative, https://amti.csis.org/the-bangladeshmyanmar-maritimedispute-lessons-for-peaceful-resolution/

\section{A list of Interviews in Ukhia and Teknaf on Bangladesh-Myanmar Border Relations:}

\section{Interviews for Primary Data in Ukhia}

1. Dr. Jamal Uddin, Principal Scientific Officer, Bangladesh Agricultural Research Institute, BARI, also a local citizen of Ukhia

2. Jahagir Kabir Chowdhury, Chairman, Rajapalong Union Parishad

3. M. Gafur Uddin Chowdhury, Chairman, Palong Khali Union Parishad

4. Master Nurul Alam Kutubi, a Retired Head Teacher, Palong Khali High School

5. Master Moulavi Shamsul Haq, Retired Government Primary School Teacher

6. Moulavi Sultan Ahmed, a Retired High School Teacher

7. Syed Nur, Assistant Professor, Hashemia Alia Madrasah

8. Hussain Mahmud Arafat, Senior Officer, Sonali Bank, Teknaf Branch, a local citizen of Ukhia

9. Advocate M. A Malek, Lawyer, Social Activist and Businessman

10. Ali Ahamed, a Political leader, Social activist and Businessman

11. Altaz Ahamed, President, Thaing Khali High School, Rahamater Bill Primary School and South Rahamater Bill Jame Masjid and Furkania Madrasah

12. Shahadat Hussain Jewel, a Social Activist and Political Leader

13. Rafiqul Kabir, Social Activist and Businessman, currently living in France, interview has been taken via messenger of social media

14. Mohammad Aziz Ullah, Head teacher, Rahamater Bill Primary School in Ukhia

15. Alhaj Ahmad Ullah, a Local Political Leader and Business Person

16. Faruq Ahmed, Journalist of Jai Jai Din, a National Daily in Bangladesh

17. Md Nurul Kabir, Service Holder in a Pharmaceutical Company

18. Sarwar Alam Titu, a Local Chemist in Thaingkhali

19. Abul Manzur Siddiqui, a Local Businessman

20. Rashid Ahmed, President of a KG School in Thaing Khali

21. Md. Yunus Khan, Senior Assistant Teacher, Government Primary School

22. Muzibul Alam Bacchu, a Senior High School Teacher 
23. Nurul Aktar Sikdar, a Senior High School Teacher

24. Alhaj Master Norul Bashar, Ex High School Teacher and Currently a Businessman

25. Mawlana Nurul Amin Siddiqui, Islamic Scholar \& Khatib (Islamic speaker)

26. Mawlana Abu Rashed Mohammad Tayab, an Islamic Scholar \& Teacher

27. Mawlana Zakir Hussain, a Local Islamic Scholar \& Homeopathic Medical Practitioner

28. Hafez Kalim Ullah, a Local Land Owner and Social Worker

29. Alhaj Abdul Karim, a Local Businessman

30. Nurul Islam, a Local Businessman

31. Syed Hussain, a Local Farmer

32. Nurul Haq, a Local Farmer

33. Syed Alam, a Local Businessman and Farmer

34. Farid Alam, a Local Businessman and Farmer

35. Momtaz Mia, a Local Farmer

36. Muzahidul Islam Masum, a NGO Worker, who is serving at Caritas in Rohingya camps in Ukhia and Teknaf

37. Abu Rashed, a Local Small Trader and Farmer

38. Alhaj Rafiq Ullah, Former Businessman in Saudi Arabia \& Currently a Wholesale Businessman

39. Nurul Alam, a Fisherman in Naf River

40. Abul Hashem, a Day Laborer

41. Abdul Gaffar, a Local Social Worker

42. Rafiq Uddin, a Local Businessman in Rohingya Refugee camps

43. Apart from these local people, around 20 Rohingya people have been interviewed in the different camps in Ukhia and Teknaf, but due to security reasons they requested us not to mention their names.

Therefore, their names have not been mentioned here.

44. Besides, some members of law enforcing agencies have also been interviewed who have been employed in Ukhia and Teknaf for ensuring law and order situation, but on their request and security reasons their names have not been mentioned here.

45. Also, some administrative officers have been interviewed who have been posted to Ukhia and Teknaf Sub-districts, but their names and positions have not been mentioned in this reference section due to tactical and security reasons. Here it should be mentioned that the border area between Bangladesh and Myanmar is very sensitive, thus many officers decline to permit to mention their names in the research paper due to security issue that they might be targeted by the terrorist groups or smugglers. 


\section{List of Interviewees in Teknaf}

\begin{tabular}{|c|c|c|c|c|c|}
\hline $\begin{array}{l}\text { Sl } \\
\text { No. }\end{array}$ & $\begin{array}{l}\text { Name of } \\
\text { Interviewee }\end{array}$ & $\begin{array}{l}\text { Father's } \\
\text { Name }\end{array}$ & Profession & Local Address & Mobile No. \\
\hline 01 & $\begin{array}{l}\text { Adv. Nurul } \\
\text { Hossain }\end{array}$ & $\begin{array}{l}\text { Md. Kabir } \\
\text { Ahmed }\end{array}$ & Lawyer & $\begin{array}{c}\text { Kanjor Para, Word \# 05, } \\
\text { Whoaykong, Teknaf, Cox's } \\
\text { Bazar. }\end{array}$ & 01815916656 \\
\hline 02 & $\begin{array}{l}\text { Md Rabiul } \\
\text { Hasan }\end{array}$ & $\begin{array}{l}\text { Md Shah } \\
\text { Alam }\end{array}$ & Businessman & $\begin{array}{c}\text { Ward \# 7, Whoykong, } \\
\text { Teknaf, } \\
\text { Cox's Bazar. }\end{array}$ & 01821707470 \\
\hline 03 & $\begin{array}{c}\text { Lutfur Rahman } \\
\text { Sikdar }\end{array}$ & $\begin{array}{l}\text { Rausan Ali } \\
\text { Sikdar }\end{array}$ & Journalist & Daily Shamakal Barta. & 01725540486 \\
\hline 04 & $\begin{array}{l}\text { Md. Jamal } \\
\text { Uddin }\end{array}$ & $\begin{array}{l}\text { Md. Kabir } \\
\text { Ahmed }\end{array}$ & $\begin{array}{c}\text { Student } \\
\text { Political } \\
\text { Activist }\end{array}$ & $\begin{array}{c}\text { Secretary, Bangladesh } \\
\text { Student League, Whoykong } \\
\text { Union South. }\end{array}$ & 01830072430 \\
\hline 05 & $\begin{array}{l}\text { Akther } \\
\text { Hossain }\end{array}$ & Md. Sonali & Businessman & $\begin{array}{c}\text { Ward \# 9, Whoykong, } \\
\text { Teknaf, } \\
\text { Cox's Bazar. }\end{array}$ & 01660195496 \\
\hline 06 & Aman Ullah & Md. Hossen & $\begin{array}{l}\text { NGO Activist, } \\
\text { MSF(Holland) }\end{array}$ & $\begin{array}{l}\text { Naya Bazar, Ward \# 07, } \\
\text { Whoykong, Teknaf, Cox's } \\
\text { Bazar. }\end{array}$ & 01865592700 \\
\hline 07 & $\begin{array}{l}\text { Arshadur } \\
\text { Rahman }\end{array}$ & $\begin{array}{c}\text { Mokbul } \\
\text { Ahmed }\end{array}$ & Teacher, Poet & $\begin{array}{l}\text { Nila Ideal Govt. Primary } \\
\text { School. }\end{array}$ & 01846999137 \\
\hline 08 & $\begin{array}{l}\text { Adv. Jiabul } \\
\text { Alam }\end{array}$ & Abdul Gani & Lawyer & Chattagram Judge Court. & 01825289414 \\
\hline 09 & $\begin{array}{l}\text { Abu Taher } \\
\text { Misbah }\end{array}$ & Md. Sonali & NGO Activist & $\begin{array}{l}\text { Ward \# 9, Whoykong, } \\
\text { Teknaf, Cox's Bazar. }\end{array}$ & 01703836878 \\
\hline 10 & Nurun Nabi & $\begin{array}{c}\text { Jahed } \\
\text { Hossain }\end{array}$ & Teaching & $\begin{array}{c}\text { Ward No \# 3, Subrang } \\
\text { Union, Teknaf, Cox's Bazar. }\end{array}$ & 01815561411 \\
\hline 11 & Nur Kamal & Ezahar Mia & Rohingya & $\begin{array}{c}\text { Camp No\#22, Unchiprang } \\
\text { Refugee Camp, Teknaf, } \\
\text { Cox's Bazar. }\end{array}$ & 01855219095 \\
\hline 12 & Abdul Kuddus & Jamil Uddin & $\begin{array}{l}\text { Rickshaw } \\
\text { Puller }\end{array}$ & $\begin{array}{c}\text { Ward\#7, Whykong, Teknaf } \\
\text { Cox's Bazar. }\end{array}$ & 01820107585 \\
\hline 13 & Nur Bahar & Siddiq & Rohingya & $\begin{array}{c}\text { Camp No\#22, Unchiprang } \\
\text { Refugee Camp, Teknaf, } \\
\text { Cox's Bazar. } \\
\end{array}$ & 01828829126 \\
\hline 14 & Joynal Uddin & Nizam Uddin & NGO Activist & $\begin{array}{l}\text { Ward\#7, Whykong, Teknaf, } \\
\text { Cox's Bazar. }\end{array}$ & 01839568474 \\
\hline
\end{tabular}

These interviews have been collected by Saruar Alam Sikdar. Apart from the above interviews, the interviews below have been taken by the first and second authors in Teknaf.

1. Saruar Alam Sikdar, Lecturer in Political Science, $35^{\text {th }}$ BCS, Jhalokathi Government College

2. Sirajul Kader, a Service Holder in Tokyo, Japan; the interview has been taken via messenger of social media on Bangladesh-Myanmar Border Relations. Here, we would like to mention that he is a regular commentator on border issues in Cox's Bazar News. Thus his interview has been taken into consideration. Also, he is a highly educated and skilled person on the issue that we have pursued. 
3. Omar Faruq, Lecturer in Political Science, City College, Cox's Bazar

4. Adnan Mahmud Russel, Assistant Teacher in Kerontali Government Primary School

5. Ahmad Hussain, a Local Political Leader and Land Lord

6. Anamul Hussain Chowdhury Babu, a Social Activist, Organizer and Land Lord

7. ANM Farukul Islam, an Information Technology Analyst

8. Nurul Amin, a Community Leader and Small Trader

9. Mawlana Jafor Alam, an Islamic Scholar

10. Mawlana Juhur Alam, an Islamic Scholar and Private Service Holder

11. Abdul Jalil, a Local Businessman and Community Leader

12. Numan Khan, a Graduate Student of Dhaka University

13. Abdus Sabur, a Community Leader, Small Trader and Farmer

14. Abdur Rashid, a (Munshi) Document Writer in Teknaf City

15. Mawlana Shamsul Alam, a Lecturer at Rajapalong M.U Fadil Madrasah

16. Alhaj Hafez Nurul Haq, a Local Land Owner and Farmer

17. Alhaj Syed Nur, a Local land Owner and Farmer

18. Abu Bakar, a Small Trader

19. Mohammad Karim, Land Lord and Small Trader

20. Alhaj Abdus Sukur, a Businessman

21. Some NGO workers have been interviewed who have been employed in the different Rohingya camps in Teknaf, but due to security reasons their names have not been mentioned here. Besides, some daylaborers, taxi drivers, bus drivers, transport workers and construction workers have been interviewed. Besides, some fishermen, who are involved in fishing in Naf River have been interviewed, but their names were not mentioned on security ground. This is because some of the Bangladesh's fishermen were killed by Myanmar security forces in Naf River while they were fishing in the river. Also, some of the fishermen were kidnapped by the Myanmar security forces for ransom. A number of fishermen and shrimp cultivators were put into jail by the Burmese military forces by kidnapping them from the border areas. It should be clarified here that fishermen are the regular spectators of the cross-border tensions and yaba drug smuggling along the borders between Bangladesh and Myanmar. Thus, they have declined mentioning their names in the research paper based on security ground. Also some laborers, who are involved in shrimp cultivation along the border, have been interviewed, but their names have not been mentioned due to the same security reason. 
* Mr. Saruar Alam Sikdar, a Lecturer in Political Science at Jhalokathi Government College, also a member of Bangladesh Civil Service (35th BCS), is currently working as an Associate Researcher with Associate Professor Akkas Ahamed of the University of Chittagong. His areas of interests are: Borderland Studies, Comparative Politics, International Relations, and Geopolitics and Regional Economic Cooperation. Mr Saruar played a pivotal role in organizing the people for interviews. The authors of this research paper highly acknowledge his supports and cooperation in collecting primary data along the border area in Teknaf, and Rohingya refugee camps. 